\title{
KADAR BIKARBONAT SALIVA PENDERITA KARIES DAN BEBAS KARIES
}

\author{
Arief Suryadinata \\ arief_drg@yahoo.com
}

\begin{abstract}
Saliva plays a role as a buffer so that the ups and downs of the degree of acidity ( $p H)$ can be retained. salivary buffer capacity is determined by the bicarbonate concentration of $85 \%, 14 \%$ is determined by the concentration of phosphate and $1 \%$ by salivary proteins. Bicarbonate is the main component of saliva to neutralize the acid thus inhibiting the caries process. Based on the role of bicarbonate in maintaining the $\mathrm{pH}$ of saliva to remain normal, there may be differences in levels of salivary bicarbonate in subjects with caries and cariesfree. This is because subjects with dental caries have the potential for acid formation and a decrease in $\mathrm{pH}$ higher than subjects with caries-free. This study aims to determine differences in levels of salivary bicarbonate in subjects with caries and caries-free, studies are observational analytic study. Based on the result showed average levels of bicarbonate in the saliva of caries-free sample is $188.9440 \pm 7.11846 \mathrm{ppm}$ while in samples with high caries intensity is $150.9905 \pm 9.76628$ ppm, then the results of Kolmogorov-Smirnov normality test pvalue of 0.200 obtained ( $p>0.05$ ) in the sample with high intensity of caries and caries-free sample group. The results of the statistical test T-test two sample unpaired in getting the value of $p=0.000$ ( $p<0.05)$, This means there are significant differences between the levels of salivary bicarbonate in subject with caries and caries-free.
\end{abstract}

\section{PENDAHULUAN}

Menurut penelitian di negara Eropa, Amerika, dan Asia termasuk Indonesia, menyatakan bahwa 80-95\% dari anak-anak umur 18 tahun terkena karies gigi. Prevalensi penyakit karies gigi di Indonesia cenderung meningkat, Rata-rata DMF-T meningkat pada setiap dasawarsa yaitu DMF-T $=0,70$ pada tahun 1970, DMF$\mathrm{T}=2,30$ pada tahun 1980 dan menjadi DMF$\mathrm{T}=2,70$ pada tahun 1990. DMF-T merupakan presentasi dari nilai D (Decay), M (Missing), dan F (Filling) yang dihitung berdasarkan jumlah gigi yang terkena karies pada masing-masing individu (Tarigan,1990). Prosentase karies gigi bertambah dengan meningkatnya peradaban manusia (Yuyus, 1993). Menurut survey kesehatan gigi yang dilakukan oleh Direktorat Kesehatan Gigi Republik Indonesia pada tahun 1994 menyebutkan prevalensi karies gigi sebesar 73,2\%, dalam profil Kesehatan Gigi dan Mulut di Indonesia pada Pelita VI dilaporkan bahwa prevalensi adalah $90.90 \%$ dengan DMFT rata-rata 6.44 dari data Depkes RI 1999. Hal ini menimbulkan problema dalam upaya penanggulangannya. Karena itu, upaya yang perlu diprioritaskan adalah tindakan pencegahan (Sundoro,2000).

Karies gigi merupakan proses multifaktor, yang terjadi melalui interaksi antara gigi dan saliva sebagai host, bakteri normal di dalam mulut, serta makanan 
terutama karbohidrat yang mudah difermentasikan menjadi asam melaui proses glikolisis. Bakteri yang berperan dalam proses glikolisis adalah Streptococcus mutans dan Lactobacillus acidophilus, sedangkan asam organik yang terbentuk antara lain asam piruvat dan asam laktat yang dapat menurunkan $\mathrm{pH}$ saliva, $\mathrm{pH}$ plak dan $\mathrm{pH}$ cairan sekitar gigi sehingga terjadi demineralisasi gigi (Kidd and Bechal, 1992).

Pada subyek karies gigi, terutama pada lubang gigi banyak terdapat bakteri yang mampu hidup dalam suasana asam (asidogenik) dan bakteri yang dapat menghasilkan asam (asidurik), sehingga memiliki potensi pembentukan asam yang lebih tinggi, dari sisa-sisa makanan yang terdapat dalam lubang gigi, dan penurunan $\mathrm{pH}$ yang lebih yang lebih terlihat pada intensitas karies yang lebih tinggi (Nolte, 1982; Ariesanti, 2004).

Saliva mempunyai peran sebagai penyangga sehingga naik turunnya derajat keasaman $(\mathrm{pH})$ dapat ditahan, sehingga proses dekalsifikasi dapat dihambat (Amerongen et al, 1992). Senyawa organik yang terkandung di dalam saliva yang mempengaruhi $\mathrm{pH}$ terutama gugus bikarbonat, fosfat, asam karbonat, amonia, dan urea.

Kapasitas buffer saliva terutama ditentukan oleh kandungan bikarbonat, sedangkan fosfat, protein, ammonia dan urea merupakan tambahan sekunder pada kapasitas buffer (Roth and Calmes, 1981; Amerongen et al, 1992). Bikarbonat merupakan komponen organik utama dalam saliva yang berpengaruh terhadap peningkatan $\mathrm{pH}$, menurut Amerongen kemampuan buffer saliva ditentukan oleh $85 \%$ konsentrasi bikarbonat, $14 \%$ ditentukan oleh konsentrasi fosfat dan $1 \%$ oleh protein saliva. Menurut penelitian poff et al (1997) yang dikutip oleh Setijanto (1999) menyebutkan bahwa kadar bikarbonat dalam saliva sebesar 3,39 \pm 1,49 $\mathrm{mM}$ atau 206,97 ppm.

Atas dasar uraian diatas dapat diasumsikan bahwa bikarbonat merupakan komponen utama saliva dalam menetralkan asam sehingga menghambat proses karies. Bila dilihat dari peran bikarbonat dalam mempertahankan $\mathrm{pH}$ saliva agar tetap normal, kemungkinan ada perbedaan kadar bikarbonat di dalam saliva penderita karies dan bebas karies.

\section{BAHAN DAN METODE}

Bahan yang digunakan dalam penelitian ini adalah larutan $\mathrm{Ba}(\mathrm{OH})_{2}$ 
0.05M, larutan HCL 0.5M, indikator metil oranye.

Alat yang digunakan pada penelitian ini adalah peralatan destilasi dengan pendingin liebig, pipet, tabung erlenmeyer, pot obat.

Sebelum Penelitian dilaksanakan dilakukan pembersihan kalkulus terlebih dahulu pada sampel. Sampel diinstruksikan menyikat giginya dengan metode Roll selama dua menit memakai pasta gigi yang telah disediakan dengan merek dan jenis yang sama untuk masing-masing sampel, dan setelah itu puasa selama 15 menit sebelum dilakukan penelitian (Ismiyatin, 2002), prosedur dilakukan pagi hari dan sampel tidak makan dan minum sebelumnya (Setijanto, 1999). Hal tersebut dilakukan untuk mendapatkan keadaan mulut yang sama pada setiap sampel.Sampel pada kelompok bebas karies dan karies tinggi, diinstruksikan untuk meludah sebanyak $5 \mathrm{ml}$ pada pot obat, kemudian diukur kadar bikarbonat dalam saliva tersebut.

\section{Pengukuran bikarbonat}

dilakukan dengan metode titrasi balik yaitu gas $\mathrm{CO}_{2}$ yang dihasilkan dilarutkan ke dalam $\left[\mathrm{Ba}(\mathrm{OH})_{2}\right]$ atau disebut air barit. air barit dititrasi kembali dengan indikator metil oranye (Manahan, 1994).

1. Disiapkan satu set peralatan destilasi dengan pendingin Liebig.

2. Larutan sampel saliva yang telah diencerkan di pipet $10 \mathrm{ml}$ dan dimasukkan ke dalam tabung erlenmeyer.

3. Pada bagian penampang destilat diberikan $20 \mathrm{ml}\left[\mathrm{Ba}(\mathrm{OH})_{2}\right] 0.05 \mathrm{M}$.

4. tabung erlenmeyer yang berisi sampel dipanaskan, maka semua gas $\mathrm{CO}_{2}$ dari sample akan bergerak masuk ke larutan $\left[\mathrm{Ba}(\mathrm{OH})_{2}\right]$, terjadi reaksi.

5. $\left[\mathrm{Ba}(\mathrm{OH})_{2}\right]$ dititrasi kembali dengan larutan HCL $0.5 \quad \mathrm{M}$ menggunakan indikator metil oranye.

6. Titrasi dihentikan jika warna larutan menjadi oranye.

Prinsip pemeriksaan dari kadar bikarbonat saliva ini adalah menggunakan gas $\mathrm{CO}_{2}$ yang dihasilkan dari saliva yang dipanaskan, kemudian direaksikan dengan $\left[\mathrm{Ba}(\mathrm{OH})_{2}\right]$ sehingga menghasilkan air barit, air barit kemudian dititrasi dengan larutan HCL $0.5 \mathrm{M}$ menggunakan indikator metil oranye. Titrasi dihentikan hingga larutan berwarna oranye, semakin banyak jumlah larutan HCL 0.5 M yang 
dibutuhkan untuk menghasilkan warna oranye maka semakin tinggi kadar bikarbonat dalam saliva. Untuk mengetahui ada tidaknya perbedaan kadar bikarbonat di dalam saliva penderita karies dan bebas karies maka dilakukan analisis dengan menggunakan uji statistik T-test 2 sampel tidak berpasangan.

\section{HASIL DAN PEMBAHASAN}

\section{Hasil}

Berdasarkan hasil pemeriksaan yang telah dilakukan pada sampel penelitian sebanyak 20 orang bebas karies dan 20 orang dengan intensitas karies tinggi didapatkan hasil sebagai berikut.

Tabel 1. Rata-rata dan standar deviasi kadar bikarbonat pada penderita karies dan bebas karies

\begin{tabular}{|c|c|c|c|}
\hline Sampel & $\mathrm{N}$ & $\begin{array}{c}\text { Rata-rata } \\
(\mathrm{ppm})\end{array}$ & $\begin{array}{c}\text { Standar } \\
\text { Deviasi }\end{array}$ \\
\hline Bebas & 20 & 188,9440 & 7,11846 \\
Karies & 20 & 150,9905 & 9,76628 \\
Karies & & & \\
Tinggi & & & \\
\hline
\end{tabular}

Pada table 1. Dapat dilihat

bahwa rata-rata kadar bikarbonat dalam saliva sampel bebas karies adalah $188,9440 \pm 7,11846$ ppm sedangkan pada sampel dengan intensitas karies tinggi adalah $150,9905 \pm 9,76628 \mathrm{ppm}$.
Tes yang digunakan untuk menguji normalitas data kadar bikarbonat pada penderita karies dan bebas karies adalah kolmogorovsmirnov test. Dari hasil uji normalitas Kolmogorov-Smirnov didapatkan nilai $p$ sebesar 0,200 (p>0,05) baik pada kelompok sampel dengan intensitas karies tinggi maupun pada kelompok sampel bebas karies. Hal ini menunjukkan kedua kelompok sampel tersebut telah memiliki distribusi yang normal, kemudian baru kedua kelompok sampel tersebut diuji dengan menggunakan uji statistik parametrik Ttest 2 sampel tidak berpasangan.

Tabel 2. Hasil uji statistik parametrik T-test 2 sampel tidak berpasangan antara kadar bikarbonat pada penderita karies dan bebas karies

\begin{tabular}{|c|c|c|c|}
\hline & $\mathrm{t}$ & $\mathrm{df}$ & $\begin{array}{c}\text { Significant } \\
\text { (2-tailed) }\end{array}$ \\
\hline $\begin{array}{c}\text { Equal } \\
\text { variance } \\
\text { assumed }\end{array}$ & 14.045 & 38 & .000 \\
\hline $\begin{array}{c}\text { Equal } \\
\text { variance } \\
\text { not } \\
\text { assumed }\end{array}$ & 14.045 & 34.744 & .000 \\
\hline
\end{tabular}

Berdasarkan hasil perhitungan menggunakan uji statistik T-test 2 sampel tidak berpasangan pada table 2., didapatkan hasil yaitu nilai $\mathrm{p}=0,000$ $(\mathrm{p}<0,05)$ yang berarti ada perbedaan 
yang bermakna antara kadar bikarbonat di dalam saliva penderita karies dengan bebas karies. Sampel bebas karies memiliki kadar bikarbonat yang lebih tinggi dibandingkan dengan sampel yang memiliki intensitas karies tinggi.

\section{Pembahasan}

Saliva merupakan faktor pengatur keadaan asam-basa di dalam mulut yang menentukan naik turunnya $\mathrm{pH}$. Beberapa faktor yang menyebabkan terjadinya perubahan pada $\mathrm{pH}$ saliva antara lain adalah rata-rata kecepatan aliran saliva, mikroorganisme rongga mulut, dan buffer saliva. Senyawa organic yang terkandung di dalam saliva yang mempengaruhi $\mathrm{pH}$ terutama gugus bikarbonat, fosfat, asam karbonat, dan urea.

Dari hasil penelitian yang telah dilakukan, seperti yang terlihat pada table 2, memperlihatkan adanya perbedaan yang bermakna antara kadar bikarbonat saliva antara sampel bebas karies dengan sampel yang memiliki intensitas karies yang tinggi. Hal ini ditunjukkan dengan adanya nilai $\mathrm{p}=$ $0,000(\mathrm{p}<0,05)$ yang diperoleh dari hasil perhitungan menggunakan uji T-test 2 sampel tidak berpasangan.
Selain itu dari peenelitian ini didapatkan nilai rata-rata kadar bikarbonat saliva sampel bebas karies sebesar 188,9440 \pm 7,11846 ppm sedangkan pada sampel dengan intensitas karies tinggi sebesar $150,9905 \pm 9,76628$ ppm. Hal ini berarti sampel bebas karies memiliki kadar bikarbonat yang lebih tinggi dibandingkan dengan sampel yang memiliki intensitas karies tinggi.

Sesuai dengan pendapat Kidd and Bechal (1991), bahwa pada individu yang memiliki intensitas karies tinggi, penurunan $\mathrm{pH}$ lebih tampak dibanding pada intensitas karies rendah, dengan adanya gigi berlubang sebagai tempat bersembunyi sisa-sisa makanan yang kemudian akan terjadi pembusukan oleh bakteri dan dapat menyebabkan penurunan $\mathrm{pH}$ saliva. Hal ini terjadi karena adanya interaksi antara gigi dan saliva sebagai host, moikroorganisme normal di dalam mulut, serta makanan terutama karbohidrat yang mudah difermentasikan menjadi asam melalui proses glikolisis. Mikroorganisme yang berperan dalam proses glikolisis adalah Streptococcus mutans dan Lactobacillus acidophilus, hal ini sesuai dengan pendapat Mount and Hume (1998) yang menyatakan bahwa pada kelompok karies tinggi jumlah Streptococcus 
mutans dan Lactobacillus acidophilus lebuh banyak daripada penderita karies rendah atau bebas karies, sedangkan asam organic yang terbentuk antara lain asam piruvat dan asam laktat yang dapat menurunkan $\mathrm{pH}$ saliva, $\mathrm{pH}$ plak dan $\mathrm{pH}$ cairan sekitar gigi sehingga terjadi demineralisasi gigi. Kondisi ini menyebabkan $\mathrm{pH}$ saliva pada sampel dengan intensitas karies tinggi menjadi lebih rendah daripada sampel bebas karies.

Brady and Holum (1993) menyatakan bahwa semakin besar konsentrasi bikarbonat saliva maka akan semakin besar juga nilai $\mathrm{pH}$. Pendapat ini sesuai dengan persamaan bentukan pH Henderson Hasselbach seperti di bawah ini :

$$
\mathrm{pH}=\mathrm{pK}+\log \left[\mathrm{HCO}_{3}^{-}\right] /
$$

$\left[\mathrm{H}_{2} \mathrm{CO}_{3}\right]$

Persamaan ini menyatakan bahwa besarnya $\mathrm{pH}$ dipengaruhi oleh perbandingan konsentrasi bikarbonat dan asam karbonat, konsentrasi bikarbonat dan asam karbonat memegang peranan penting dalam mengendalikan nilai $\mathrm{pH}$. Menurut Amerongen (1992) disebutkan bahwa pada pH netral $\left[\mathrm{HCO}_{3}^{-}\right]$/ $\left[\mathrm{H}_{2} \mathrm{CO}_{3}\right]$ memiliki perbandingan sebesar 20:1 sedangkan pada $\mathrm{pH}$ asam $\left[\mathrm{HCO}_{3}^{-}\right]$/ $\left[\mathrm{H}_{2} \mathrm{CO}_{3}\right]$ memiliki perbandingan sebesar 4,5:1, hal ini menunjukkan bahwa konsentrasi bikarbonat lebih dominan daripada konsentrasi asam karbonat. Dengan demikian, apabila $\mathrm{pH}$ saliva rendah maka kadar bikarbonat di daalam saliva juga rendah karena komponen utama pembentuk $\mathrm{pH}$ saliva adalah bikarbonat, sehingga kadar bikarbonat saliva pada sampel dengan intensitas karies tinggi lebih rendah daripada sampel bebas karies.

Peningkatan $\mathrm{pH}$ saliva oleh kemampuan buffer bikarbonat memiliki mekanisme sebagai berikut: pada kondisi saliva asam, konsentrasi ion $\mathrm{H}^{+}$ saliva akan berlebih, untuk menetralkan kondisi ini maka akan terjadi penambahan konsentrasi bikarbonat. Reaksi antara ion $\mathrm{H}^{+}$dan bikarbonat menghasilkan asam karbonat $\left(\mathrm{H}_{2} \mathrm{CO}_{3}\right)$. Asam karbonat yang terjadi akan segera berubah menjadi air $\left(\mathrm{H}_{2} \mathrm{O}\right)$ dan gas karbondioksida $\left(\mathrm{CO}_{2}\right)$, sehingga dengan penambahan konsentrasi bikarbonat, $\mathrm{pH}$ saliva akan kembali netral (Caranza, 2002; Amerongen et al, 1992; Brady and Holum, 1993).

Bikarbonat merupakan senyawa basa yang dapat menetralkan kondisi 
asam (Amerongen et al, 1992; Brady and Holum, 1993). Bikarbonat dapat menetralkan keasaman saliva dengan mengikat ion hidrogen, hasil reaksi ini akan membentuk air $\left(\mathrm{H}_{2} \mathrm{O}\right)$ dan karbondioksida $\quad\left(\mathrm{CO}_{2}\right) . \quad$ Sebagai akibatnya apabila kadar bikarbonat mencukupi $\mathrm{pH}$ saliva yang asam meningkat menjadi normal $(\mathrm{pH}=7,00)$ (Amerongen et al, 1992).

\section{KESIMPULAN}

1. Terdapat perbedaan kadar bikarbonat saliva antara subyek penderita karies dan subyek bebas karies

2. Subyek dengan intensitas karies tinggi memiliki kadar bikarbonat saliva lebih rendah daripada subyek bebas karies

\section{DAFTAR PUSTAKA}

Amerongen, AVN. Michels, LFE. Roukema, PA. Veerman, ECI. 1992. Ludah dan Kelenjar Ludah Bagi Kesehatan Gigi. Terjemahan Abyono R. Suryo S. Cetakan kedua. Yogyakarta. Gadjah Mada University Press. hlm. 23-41.

Ariesanti, Y. Hartini, T. Musdhalifah, A. Roeslan, B. 2004. Perbedaan Kadar Urea di dalam Saliva Penderita Karies Dan Bebas Karies. Majalah Ilmiah Kedokteran Gigi FKG Usakti, Th. 19, No. 43. hlm. 135-139.
Brady, J.E. Holum, J.R. 1993. Chemistry. The study of matter and its changes. New York Chichester Brisbane Toronto Singapore. Jhon Wiley \& sons.inc

Carranza, FA. 2002. Glickman's Clinical Periodontology. 10th.ed. Philadelphia London Toronto Montreal Sidney Tokyo. W.B. Saunders Company. p. 186-187.

Finn, S.B. 1973. clinical pedodontics, $4^{\text {th }}$ edition. W.B. Saunders Company. Philadelphia, London, Toronto. P 475-492.

Houwink, B. 1993. Karies Gigi. Ilmu Kedokteran gigi Pencegahan Yogyakarta. Gadjah Mada University Press. Hlm 125-126.

Ismiyatin, K. 2002. Perbedaan Efektivitas Bufer Saliva Penderita Karies Rendah dan Tinggi Setelah Kumur Larutan Sukrosa 10\% Sebelum dan Sesudah Penumpatan. Karya Tulis Akhir Program Spesialis Konservasi Gigi. Hlm. 32-38.

Kidd,EAM. dan Bechal, SJ. 1992. Dasar-Dasar Karies : Penyakit dan Penanggulanggannya. Jakarta. EGC. hlm. 1-4, 66-78.

Manahan, S.E. 1994. Environment Chemistry 6th Ed. Boca Raton Ann Aibar London Tokyo CRCPress, Inc. Lewis Publishers.

Mount, GJ. Hume, WR. 1998. Preservation and Restoration of Tooth Structure, 1st ed, Mosby international Ltd, London Tokyo, p 9-17.

Nolte WA. 1982. Oral Microbiology with Basic Microbiology and Immunology. 4th Ed. St Louis. 
Mosby. p. 287-289, 304-305, 309310, 336-338.

Olofsson, $\mathrm{M}$ and Bratthal, D. Diagnostic-Dental Caries Clinical Investigation. Available from http://www.db.od.mah.se/car/data/ clin.html. .cited 2008 jan 18.

Poff, A.M. Pearce, E.I.F. Larsen, M.J. Cutress, T.W. 1997. Human Supraginggival in Vivo Calculus Formation in Relation to Saturation of Saliva with Respect to CalciumPhosphates. Archieves Oral Biology, vol. 42 (2).

Roth, G.I. Calmes, R. 1981. Oral Biology. St.Louis Toronto London. The CV. Mosby Company. p. 197-198, 217-218, 227-228.

Sastroasmoro, Sudigdo. 1995. DasarDasar Metodologi Penelitian Klinis. Jakarta: Binarupa Aksara. H.196.

Setijanto, RD. 1999. Kadar Amonia Saliva Istirahat Sebagai Pemicu Pembentukan Karang Gigi Supragingiva. Disertasi Pasca Sarjana Universitas Airlangga. hlm. 35-39.
Sundoro, EH. 2000. Konsep Baru Perawatan Karies. http://www.pdpersi.co.id/pdpersi/ news/artikel.php3?id=107.28-072007 13:00 WIB.

Suwelo, IS. 1992. Karies Gigi Pada Anak Dengan Pelbagai Faktor Etiologi (Kajian Pada Anak Usia Prasekolah). Jakarta. EGC.

Tarigan, R. 1990. Karies Gigi. Medan. Hipokrates.

Yusuf, AA, dkk. 1992. Metoda Penelitian dan Statistik Terapan. FK Universitas Airlangga. Surabaya. Hlm. 63-66.

Yuyus R, Magdarina DA, Sintawati F. 2002. Karies Gigi pada Anak Balita di 5 Wilayah DKI tahun 1993. Cermin Dunia Kedokteran. Jakarta. No. 134. hlm. 1-5.

World Health Organization. Oral Health Country Area Profile Program.Caries for 12 years old by Country/area [cited 2008 january 18]. Available at http://www.whocollab.od.mah.se/ countriesalphab.html. 